\title{
The Potentiality of Tourism Resources in Hulu Sungai Selatan Regency, South Kalimantan
}

\author{
Ellyn Normaleni* \\ Study Program of Geography Education, Faculty of Teaching and Education Science, Lambung Mangkurat University, \\ Banjarmasin, Indonesia
}

\section{Abstract}

Hulu Sungai Selatan regency, South Kalimantan, has potentiality to be developed as tourism destinations. It is especially important for local economic development, cultural preservation, and natural resources conservation. The objective of the research is to identify the tourism potentiality in Hulu Sungai Selatan regency. Result of the study shows that Hulu Sungai Selatan Regency has numerous potential tourism objects, ranging from man-made to natural attractions. On the future development, special interest tourism such as nature-based tourism, ecotourism, culinary tourism religious tourism, history and cultural tourism are potentials to be developed. The sustainable principles of tourism practices should be adopted by local government in every aspect of tourism development. It is especially crucial for natural resources and biodiversity protection; while in the same time enhance the quality of attraction and destination.

Keywords: ecotourism, Hulu Sungai Selatan, tourism development, tropical conservation.

\section{INTRODUCTION}

South Kalimantan province in Indonesia is especially important for tropical biodiversity conservation and cultural preservation. South Kalimantan is home for numerous plant and animal biodiversity, in which some of them area globally endemic to the South Kalimantan. The biodiversity of South Kalimantan is important for global economic life, but many biodiversity and wildlife habitat recently under threats. There are needs significant strategy to promote environmental conservation in South Kalimantan [1].

Culturally, South Kalimantan rich in term of cultural ethnicity, in which Banjarese group are the majority of ethnic of group. One of unique culture was floating market, in which market occurs in the Barito River. The interaction between trader and costumer occur using traditional boat (called jukung) and in many case the transaction was implemented through barter system. There are also numerous traditional ceremony, that influenced by Islam and Dayaks belief traditions. Dayaks is the indigenous people groups of Kalimantan, in which in some aspect influence the culture and traditions of people in Kalimantan[2,3].

South Kalimantan consists of some regency, in which culturally and naturally this regency shows specific characters. It is becomes the

\footnotetext{
${ }^{*}$ Correspondence address:

Ellyn Normaleni

Email : ellyne_melani@yahoo.co.id

Address : Lambung Mangkurat University, Brigjen Haji Hasan Basri, Banjarmasin 70124
}

potentiality of south Kalimantan province to develop numerous form of tourism sectors. The development of tourism sector in Hulu Sungai Selatan relevant with the provincial government related to the Provincial Tourism Master Plan, as stated in the Medium Term Development Planning of South Kalimantan Province 20102015. According the document, Hulu Sungai Selatan includes as the regional tourism development of South Kalimantan province. Focus of development put Loksado as the capital city in Hulu Sungai Selatan.

The development of ecotourism is relevant with the effort to increase local economic growth, local culture preservation, and environmental conservation. In many case, ecotourism has been selected as a strategic tools for development $[4,5,6]$. While there are many natural-cultural resources potential in South Kalimantan associated with the development of tourism are beneficial to local economic development, there is little systematic on the resources evaluation. It is especially important for many regions in South Kalimantan, especially Hulu Sungai Selatan. The aims of the study are to identify and to describe the potentiality of tourism resources in Hulu Sungai Selatan for future tourism development.

\section{MATERIAL AND METHODS}

Data was collected in Hulu Sungai Selatan through field trip and direct observation. Firstly, the potentials of tourism attraction was identified though secondary data and local 
government document related to the development of tourism in Hulu Sungai Selatan Regency. The field trip explores the natural, cultural, and historical and aspects related to amenity and accessibility of region, with special focus on the role of such resources as part of the tourism destination component. Data was compiled and analyzed for further analysis. The secondary data was collected from numerous institutions dealing with this study. Field trip was performed not only for direct observation but also for verification of the secondary data. Data was analyzed descriptively.

\section{RESULT AND DISSCUSSION \\ Profile of Hulu Selatan Regency}

Hulu Sungai Selatan is one of the regency in South Kalimantan Province. Geographically, it is located at $02^{\prime} 29^{\prime \prime} 58^{\circ} \mathrm{S}-02^{\prime} 56^{\prime \prime} 10^{\circ} \mathrm{S}$ and $114^{\prime} 51^{\prime \prime} 19^{\circ} \mathrm{E}-115^{\prime} 36^{\prime \prime} 19 \mathrm{E}$. The regency covers an area about $1,804.94 \mathrm{~km}^{2}$. The Hulu Sungai Selatan regency consists of 11 districts, 4 suburban area (kelurahan), and 114 villages (desa). Administratively, the regency is surrounded by Hulu Sungai Tengah Regency and Hulu Sungai Utara Regency in the north, Hulu Sungai Tengah Regency and Kotabaru Regency in the east, Tapin Regency in the south, and Hulu Sungai Utara
Regency and Tapin Regency in the west (Fig. 1). The distribution area in Hulu Sungai Selatan Regency was shown in Table 1.

Topography profile of Hulu Sungai Selatan regency is dominated by flat land area. Most of the flat area (0-25 $\mathrm{m}$ above sea level) was located at the west area of the regency. Totally, the flat area was calculated about 123,452 ha or equal to $\pm 68 \%$ of the area of Hulu Sungai Selatan Regency (Table 2).

Soil texture in Hulu Sungai Selatan regency can be classified into two types, smooth and medium. The average of rainfall was about $1,819.5 \mathrm{~mm}$ with rain fall days number was about 181 days. The average of temperature was about $26.25^{\circ} \mathrm{C}-27.25^{\circ} \mathrm{C}$ and the humidity was about $76,5 \%-77 \%$.

The characteristic of land uses in Hulu Sungai Selatan Regency in 2010 was dominated by paddy field. It was calculated about $33.17 \%$. The second largest class was peat swamp about $33.03 \%$. The smallest part of the land classification was orchards. It was calculated about 350 ha or equal to $0.25 \%$ of the total area of Hulu Sungai Selatan Regency. For the building area, i.e. settlement was about 1.978 ha or equal to $1.39 \%$ of the total area.

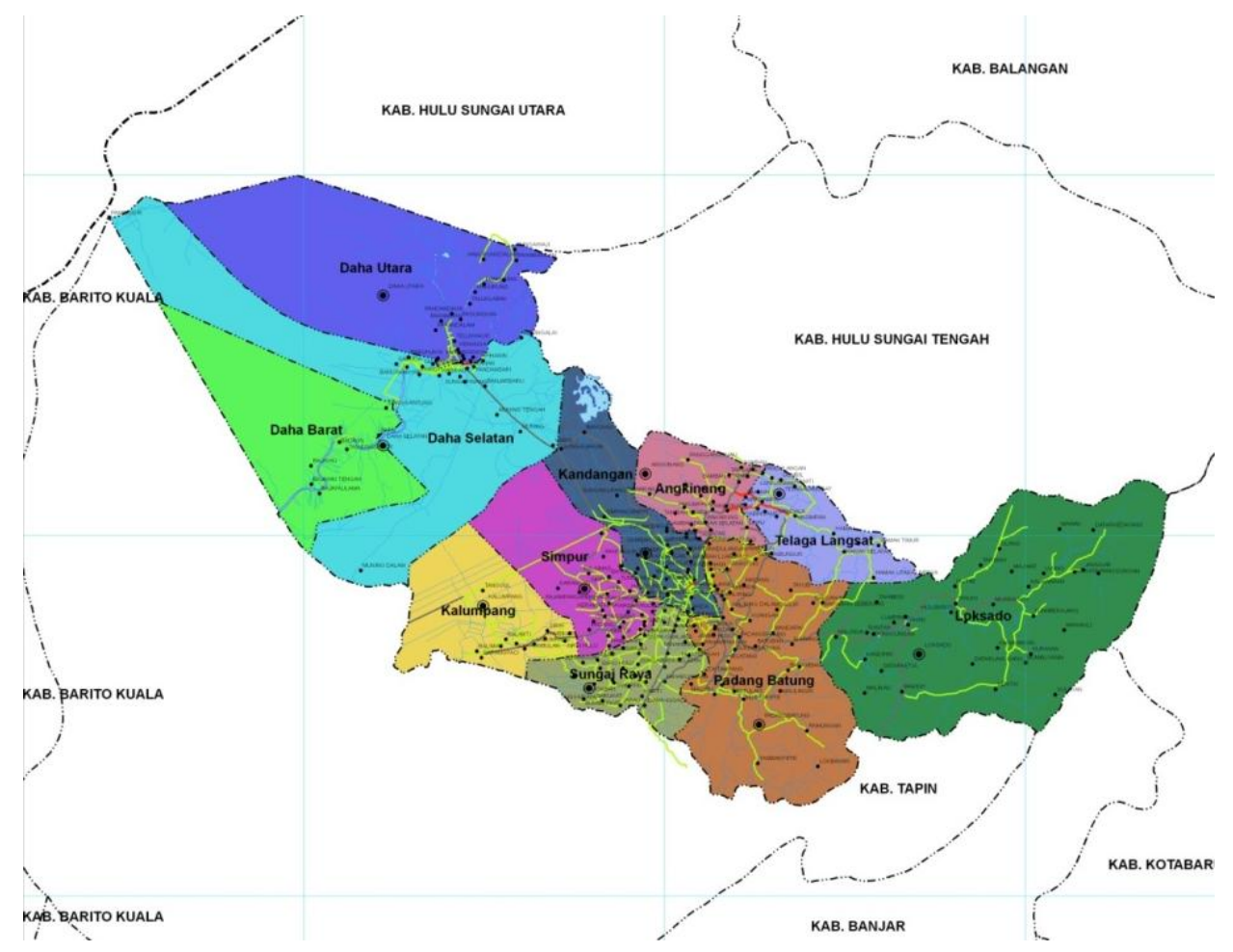

Figure 1. The area of Hulu Sungai Selatan Regency Source: Regional Development and Planning Agency of Hulu Sungai Selatan [7] 
Tourism Resources in Hulu Sungai Selatan Regency, South Kalimantan (Normaleni)

Table 1. Area Distribution in Hulu Sungai Selatan, 2010

\begin{tabular}{|c|c|c|c|c|}
\hline No. & District & Main town & Area $\left(\mathrm{km}^{2}\right)$ & Number of sub-urban/villages \\
\hline 1 & Padang Batung & Padang Batung & 203.3 & 17 \\
\hline 2 & Loksado & Loksado & 338.89 & 11 \\
\hline 3 & TelagaLangsat & TelagaLangsat & 58.08 & 11 \\
\hline 4 & Angkinang & Angkinang & 58.40 & 11 \\
\hline 5 & Kandangan & Kandangan & 106.71 & 18 \\
\hline 6 & Sungai Raya & Sungai Raya & 80.96 & 18 \\
\hline 7 & Simpur & Simpur & 82.35 & 11 \\
\hline 8 & Kalumpang & Kalumpang & 135.07 & 9 \\
\hline 9 & South Daha & Tumbukan Banyu & 322.80 & 16 \\
\hline 10 & North Daha & TambakBitin & 268.11 & 19 \\
\hline \multirow[t]{2}{*}{11} & West Daha & Bajayau & 149.62 & 7 \\
\hline & Total area & & 1804,92 & 148 \\
\hline
\end{tabular}

Sources: Statistics Hulu Sungai Selatan Regency [8]

Table 2. The Topography of Hulu Sungai Selatan Regency

\begin{tabular}{lc}
\hline Class & Land area (ha) \\
\hline $0-7 \mathrm{~m}$ & 105,198 \\
$7-25 \mathrm{~m}$ & 18,254 \\
$25-100 \mathrm{~m}$ & 16,590 \\
$100-250 \mathrm{~m}$ & 17,126 \\
$250-500 \mathrm{~m}$ & 10,420 \\
$500-1000 \mathrm{~m}$ & 11,226 \\
$>1000 \mathrm{~m}$ & 1,680 \\
\hline Total land area & $\mathbf{1 8 0 , 4 9 4}$
\end{tabular}

Agricultural area of Hulu Sungai Selatan Regency was distributed at the southern area in 11 districts, in which paddy is the dominant agricultural commodity. The forest in Hulu Sungai Selatan distributed patchily. The protected forest is calculated about $23,919.52$ ha and the conservation-production forest is about $18,724.46$ ha. Plantation in Hulu Sungai Selatan regency distributed unevenly. Plantation was managed based on community. The commodity which area planted in plantation system are including rubber, coconut, clove, pepper, cinnamon, coffee, cacao, and candlenut.

\section{Tourism Attraction Diversity}

There are numerous forms of tourism that can be developed as tourism machine in Hulu Sungai Selatan. The tourism policy of Hulu Sungai Selatan views cultural tourism and nature based tourism as focus of development. As far, the comprehensive data of tourism was absent, represent the poor management of tourist recording system. It becomes the limitation for tourism planning and management because poor of statistical data to support planning and decision. Some data has found in Loksado, the very famous nature based tourism destination.

\section{Cultural tourism}

Cultural aspect of local people is the potential resources for future tourism development, especially in term of attraction and destination hospitality [4,9]. According to scholar, every community that lived in the earth had specific culture, and every culture is unique. South Kalimantan rich in term of cultural capital, which is possible to be developed for future cultural tourism (Table 3). The traditional ceremony such as Aruh Ganal (Fig. 2) presents as gratitude ceremony to God, for their fine life.

Table 3. Potential Cultural Tourism Attraction

\begin{tabular}{lll}
\hline Cultural Tourism & Location \\
\hline 1. & $\begin{array}{l}\text { Dayak house (Balai Adat } \\
\text { Dayak) }\end{array}$ & Loksado District \\
2. Banjar Traditional House & Humbungan Tinggi & Habillage, South \\
Daha District & Amawang Village, \\
3. Banjar Traditional House & Kajah Menyusu & Hulu Sungai Selatan \\
4. Aruh Ganal traditional & Regency \\
ceremony & Hulu Sungai Selatan \\
5. Numerous traditional art & Regency \\
6. Traditional boat (Jukung or & South Daha \\
Perahu Naga) competition & Hraditional games & Hulu Sungai Selatan \\
7. & Regency \\
8. Kalang Hadangan & North Daha \\
\hline
\end{tabular}

There are needs on preservation strategy of cultural assets. It is especially important to provides sustainable cultural attraction for the future. In the perpective where rapid 
modernization occurs in South Kalimantan, the preservation of cultural aspect is important.

\section{Historical Tourism}

As part of the Indonesia, the history of South Kalimantan has close relation with the past history of Indonesia. In the past, before the Independency of Indonesia, some area in South Kalimantan is autonomic kingdom under sultanate system with Islam as the main religion.

Table 4. Historical Tourism Assets

\begin{tabular}{|c|c|c|}
\hline \multicolumn{2}{|c|}{ Historical Assets } & \multirow{2}{*}{$\begin{array}{l}\text { Location } \\
\text { Ni'ih village, Loksado } \\
\text { District }\end{array}$} \\
\hline 1. & $\begin{array}{l}\text { The monument of Teks } \\
\text { Proklamasi Gubernur } \\
\text { Tentara ALRI Divisi IV } \\
\text { Pertahanan Kalimantan } \\
17^{\text {th }} \text { May } 1949\end{array}$ & \\
\hline 2. & $\begin{array}{l}\text { The monument of } \\
\text { Peringatan Penyusunan } \\
\text { Teks Proklamasi Gubernur } \\
\text { Tentara ALRI Divisi IV }\end{array}$ & Telaga Langsat District \\
\hline 3. & $\begin{array}{l}\text { The monument of } \\
\text { Peringatan Peristiwa } \\
\text { Pemencaran Pasukan } \\
\text { ALRI Divisi IV } 10^{\text {th }} \text { May } \\
1949\end{array}$ & $\begin{array}{l}\text { Pagat Batu, Batu village } \\
\text { in Padang Batung } \\
\text { District }\end{array}$ \\
\hline 4. & $\begin{array}{l}\text { The monument of } \\
\text { Gencatan Senjata Antara } \\
\text { Gubernur Tentara ALRI } \\
\text { Divisi IV - NICA }\end{array}$ & Sungai Raya District \\
\hline 5. & $\begin{array}{l}\text { The monument of } \\
\text { Mandapai, Upacara HUT } \\
\text { ke-IV RI } 17^{\text {th }} \text { August } 1949\end{array}$ & $\begin{array}{l}\text { Mandapai Village, } \\
\text { Padang Batung District }\end{array}$ \\
\hline 6. & $\begin{array}{l}\text { The monument of } \\
\text { Palagan Negara } 2^{\text {nd }} \\
\text { January } 1949\end{array}$ & $\begin{array}{l}\text { Hakurung Village, North } \\
\text { Daha District }\end{array}$ \\
\hline 7. & $\begin{array}{l}\text { The monument of Garis } \\
\text { Demarkasi }\end{array}$ & $\begin{array}{l}\text { Karang Jawa Village, } \\
\text { Padang Batung District }\end{array}$ \\
\hline 8. & $\begin{array}{l}\text { The monument of } \\
\text { Peringatan Markas } \\
\text { Daerah Divisi IV ALRI } \\
\text { Pertahanan Kalimantan }\end{array}$ & $\begin{array}{l}\text { Jelatang Village, Padang } \\
\text { Batung District }\end{array}$ \\
\hline 9. & $\begin{array}{l}\text { The building of Gedung } \\
\text { JuangDivisi IV ALRI } \\
\text { Pertahanan Kalimantan }\end{array}$ & $\begin{array}{l}\text { Hamalau Village, Sungai } \\
\text { Raya District }\end{array}$ \\
\hline & Benteng Madang sites & $\begin{array}{l}\text { Madang Village, Padang } \\
\text { Batung District }\end{array}$ \\
\hline 11. & Amuk Hantarukung sites & $\begin{array}{l}\text { Hantarkurung Village, } \\
\text { Simpur District }\end{array}$ \\
\hline 12. & Tomb of Tumpang Talu & $\begin{array}{l}\text { West Kandangan, } \\
\text { Kandangan District }\end{array}$ \\
\hline 13. & Tomb of Anam & $\begin{array}{l}\text { Ida Manggala Village, } \\
\text { Sungai Raya District }\end{array}$ \\
\hline 14. & Tomb of Singakarsa & $\begin{array}{l}\text { Singakarsa street, } \\
\text { Kandangan District }\end{array}$ \\
\hline 15. & Tomb of Aluhldut & $\begin{array}{l}\text { Iluhldut street, } \\
\text { Kandangan District }\end{array}$ \\
\hline 16. & . Tomb of Ning Bulang & $\begin{array}{l}\text { Hantarkurung village, } \\
\text { Simpur District }\end{array}$ \\
\hline 17. & Historical building & $\begin{array}{l}\text { Hulu Sunagai Selatan } \\
\text { Regency }\end{array}$ \\
\hline
\end{tabular}

The role of Islam in cultural aspect of South Kalimantan was important. The contribution of the effort to become independence community under Republic Indonesia has also contributed to the number of historical tourism assets. The potential assets of historical tourism is seen in Table 4.

\section{Religious tourism}

Moslem is the majority religion in South Kalimantan, and therefore Islamic spirit contributes significantly in daily local life and traditions. There are numerous Islamic heritages which area recently visited by tourist, especially domestic tourist and respected tombs, which are visited by people (Table 5).

Table 5. Potential Religious Tourism Attraction

\begin{tabular}{|c|c|}
\hline Religious Attraction & Location \\
\hline 1. Su'ada Mosque & $\begin{array}{l}\text { Wasah Hilir Village, Simpur } \\
\text { District }\end{array}$ \\
\hline 2. Tomb of H.M Said & $\begin{array}{l}\text { Simpur Village, Simpur } \\
\text { District }\end{array}$ \\
\hline $\begin{array}{l}\text { 3. Tomb of Datu } \mathrm{H} \text {. } \\
\text { Abbas }\end{array}$ & $\begin{array}{l}\text { Simpur Village, Simpur } \\
\text { District }\end{array}$ \\
\hline $\begin{array}{l}\text { 4. Dome of Datu } \\
\text { Durabu }\end{array}$ & $\begin{array}{l}\text { Kalumpang Village, } \\
\text { Kalumpang District }\end{array}$ \\
\hline $\begin{array}{l}\text { 5. Dome of Datu } \\
\text { Akhmad }\end{array}$ & $\begin{array}{l}\text { Balimau Village, Kalumpang } \\
\text { District }\end{array}$ \\
\hline 6. Dome of Taniran & $\begin{array}{l}\text { Taniran Village, Angkinang } \\
\text { District }\end{array}$ \\
\hline $\begin{array}{l}\text { 7. Sacred tomb of Datu } \\
\text { H.M Rais }\end{array}$ & $\begin{array}{l}\text { Loknyiur Village, Angkinang } \\
\text { District }\end{array}$ \\
\hline 8. Tomb of Datu Daha & North Daha District \\
\hline 9. Tomb of Surgi Tuan & $\begin{array}{l}\text { Pasungkan Village, North } \\
\text { Daha District }\end{array}$ \\
\hline $\begin{array}{l}\text { 10. Tomb of Habib } \\
\text { Iberahim }\end{array}$ & Mandala, North Daha District \\
\hline $\begin{array}{l}\text { 11. Tomb of Tuan Guru } \\
\text { Haji Ali }\end{array}$ & $\begin{array}{l}\text { Pandan Sari Village, South } \\
\text { Daha District }\end{array}$ \\
\hline $\begin{array}{l}\text { 12. Tomb of Habib } \\
\text { Lumpangi }\end{array}$ & $\begin{array}{l}\text { Lumpangi Village, Loksado } \\
\text { District }\end{array}$ \\
\hline
\end{tabular}

The history of South Kalimantan shows that the Banjarese Kingdom accepts Islam as a belief and used Islamic spirit as a fundamental aspect in community life manage-ment. The development of religios tourism is crucial for tourism in South Kalimantan. It is especially relevant with the recent trend in tourism development in Indonesia.

\section{Nature based-tourism}

Nature based tourism attraction and destination were found numerous in Hulu Sungai Selatan. While many areas in South Kalimantan has been degraded, some area in Hulu Sungai Selatan is still remained and provides excellent 
habitat for wildlife and provides environmental services which are potential to developed as the tourist attraction (Table 6).

Table 6. Potential Nature-based Tourism Attraction

\begin{tabular}{|c|c|c|}
\hline No. & Natural Attraction & Location \\
\hline 1 & $\begin{array}{l}\text { Loksado Nature-based } \\
\text { tourism }\end{array}$ & Loksado District \\
\hline 2 & Haratai waterfall & Loksado District \\
\hline 3 & $\begin{array}{l}\text { Tanuhi hot spring } \\
\text { water }\end{array}$ & $\begin{array}{l}\text { Tanuhi village, Loksado } \\
\text { District }\end{array}$ \\
\hline 4 & Mt. Kantawan & $\begin{array}{l}\text { Tanuhi village, Loksado } \\
\text { District }\end{array}$ \\
\hline 5 & Lake Bangkau & Kandangan District \\
\hline 6 & $\begin{array}{l}\text { Delta and Dam of } \\
\text { Amandit river }\end{array}$ & $\begin{array}{l}\text { Malutu Village, Padang } \\
\text { Batung District }\end{array}$ \\
\hline 7 & Riam Anai & $\begin{array}{l}\text { Lok Lahung, Loksado } \\
\text { District }\end{array}$ \\
\hline 8 & Kilap Api Waterfall & $\begin{array}{l}\text { Tanuhi Village, Loksado } \\
\text { District }\end{array}$ \\
\hline 9 & Uring waterfall & $\begin{array}{l}\text { Kamawakan village, } \\
\text { Loksado District }\end{array}$ \\
\hline 10 & Tangkaramin waterfall & $\begin{array}{l}\text { Malinau village, Loksado } \\
\text { District }\end{array}$ \\
\hline 11 & $\begin{array}{l}\text { Tinggiran Hayam } \\
\text { waterfall }\end{array}$ & $\begin{array}{l}\text { Kamawakan Village, } \\
\text { Loksado District }\end{array}$ \\
\hline 12 & Mandapai Hot water & $\begin{array}{l}\text { Bini Village, Padang } \\
\text { Batung District }\end{array}$ \\
\hline 13 & Lake Bidadari & $\begin{array}{l}\text { Telaga Bidadari village in } \\
\text { Sungai Raya District }\end{array}$ \\
\hline
\end{tabular}

The development of tourism can cause damage to natural resources if these resources are used excess and mismanagement. Involving local people in the tourism business, people no longer use natural resources (e.g. wood, sand, stone, etc.) as a livelihood. In addition, involving local communities in making decisions is important in tourism management to assure the quality of their lives in the future [10].

\section{Culinary and Art Tourism}

Hulu Sungai Selatan is rich in term of cuisines, which can be developed in culinary tourism. The impact of Banjarese and Javanese traditions produce numerous cuisines of Hulu Sungai Selatan (Table 7). Various hand crafting are also available in the study area. Rattan and bamboo often made into mats, basket, bag, etc (Fig. 3). The crafting is usually made by Dayak women.

Table 3. Potential Culinary and Art Tourism Attraction

\begin{tabular}{|c|c|}
\hline Attraction & Location \\
\hline 1. Ketupat* & All districts \\
\hline $\begin{array}{l}\text { 2. Cake "Dodol } \\
\text { Kandangan" }\end{array}$ & $\begin{array}{l}\text { culinary centre in Sungai Raya } \\
\text { District }\end{array}$ \\
\hline 3. Crackers & $\begin{array}{l}\text { Bamban Villages, Angkinang } \\
\text { District }\end{array}$ \\
\hline 4. Craft of metal/brass & South and North Daha District \\
\hline
\end{tabular}

5. Craft of jewelry and
accessories
6. Traditional weapon
$\begin{aligned} & \text { Mandau handicraft } \\ & \text { 7. Pottery }\end{aligned}$

*Note: ketupat is boiled rice in coconut leaf wrap, served with coconut soup ingredients

\section{Accessibility}

The tourism attraction in Hulu Sungai Selatan can be accessed from numerous town and city surrounding Hulu Sungai Selatan. Terrestrial road is the backbone of accessibility. The road was available, and according to national road standard classified as Road Class III A, III B and IIIC. Hulu Sungai Selatan has many rivers. Therefore, there are 15 bridges of steel and 22 bridges of wood.

Most tourist attraction is difficult to reach because of road conditions and limited only accessible by private vehicle. Some bridges (wooden bridges) are old and broken. In some places, there is no public transport available. Another problem is the lack of adequate tourist facilities and poor management. There is a conflict between local governments and local communities in the management of attraction. In addition, the land where the tourist attraction are on land owned by the community also become an obstacle.

Improvement should be done in some aspects, including improving safety and quality of roads, corridors system for tourist movement, and public transportation that are able to support tourism movement. Access to tourist attraction and destination has also been associated with river corridors in the specific area. Therefore, providing river transportation is also important. Several areas have bamboo rafting as river transportation, in additional to a new experience to travel with bamboo rafting. The bamboo rafting was steered by local people. Each rafting accommodates 2-4 persons, as seen in Figure 4.

\section{Amenity}

Amenity for tourism includes accommodation, restaurant, heath infrastructure, bank and other aspects supporting tourism business. The availability of amenity instrument was important to the destination. Poor of amenity instrument becomes the crucial aspect for destination competitiveness, in which destination with poor amenities has identified difficult to generate tourism. 


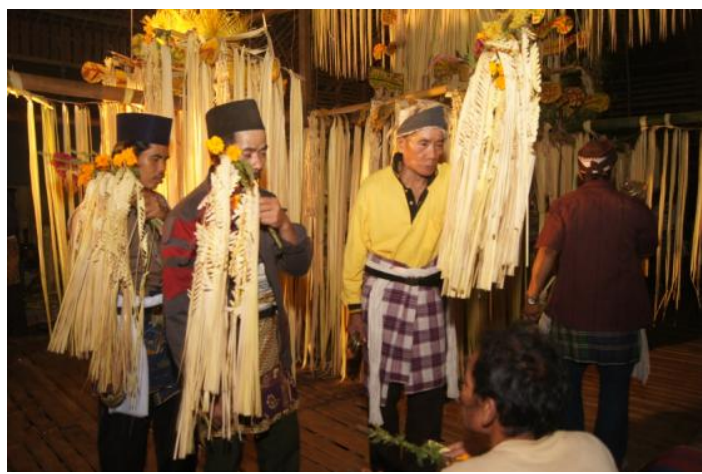

Figure 2. Aruh Ganal Traditional Ceremony
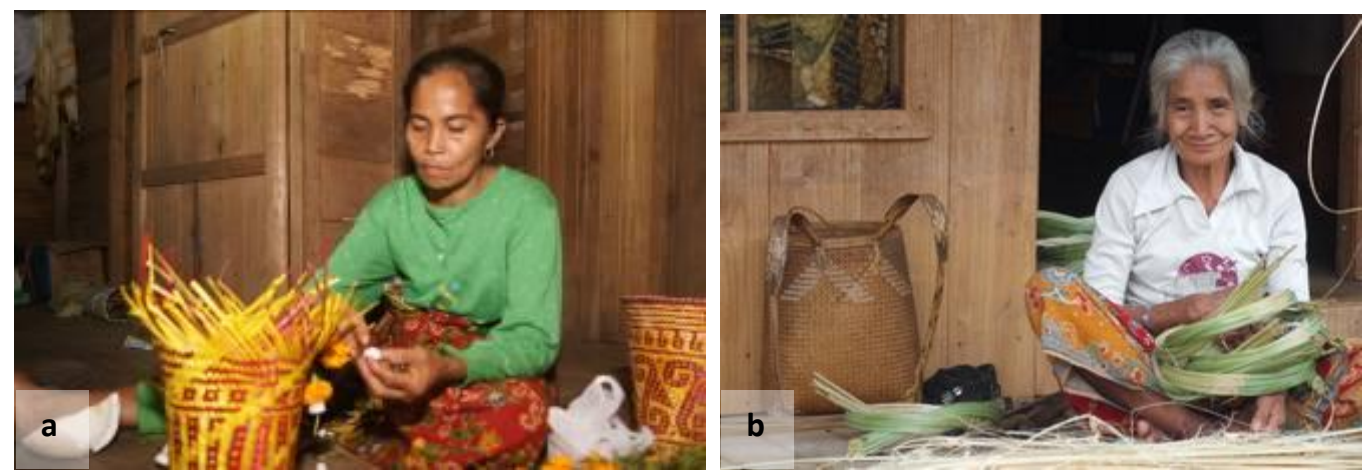

Figure 3. Handicraft of Rattan by Dayak Women. a. Basket handicraft, and b. Bag handicraft
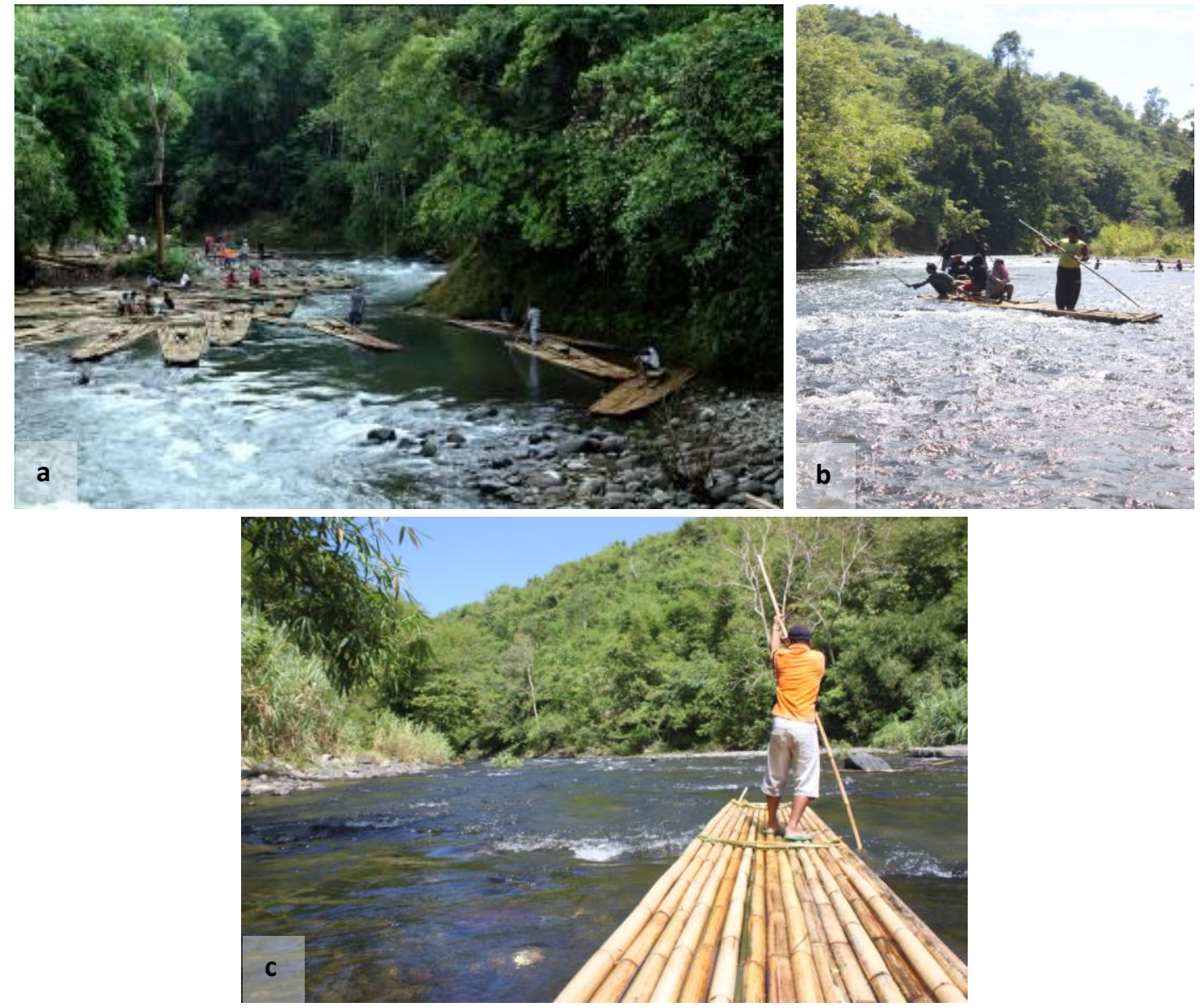

Figure 4. Bamboo Rafting

a. bamboo rafting port, $\mathbf{b}$. bamboo rafting with passengers, and $\mathbf{c}$. experiencing bamboo rafting as passenger 
There are accommodations in Hulu Sungai Selatan, such as Hot spring water hotel in Tanuhi, Wisma Loksado Hotel, Graha Amandit Hotel, Bangkau Hotel, Loksado Hotel, Mutia Hotel, Wisma Duta Hotel and Mahligai Antaludin Hotel. These are distributed around the city, but rarely accommodation found near attractions. There is no evidence of the existence of accommodation which is owned and managed by local people or community.Most of privately managed hotel is in good condition, clean, and well maintained. This is different from the situation of TanuhiCottage that is not well maintained. Tanuhi Cottage is managed by the tourism department of Hulu Sungai Selatan district. There are 10 units (for 20 people) cottage with a unique architecture that is equipped with swimming pools, hot tubs, hot tubs bubble, cafeteria, office managers, roads and bridges, sanitation, postal security, tennis courts, as well as a relaxing/break places. In addition, tourists complaint that telecommunications signals are very weak.

About 44 restaurants were registered in Hulu Sungai Selatan. These restaurants are able to serve tourist in term of culinary aspect. The restaurants contribute to purpose in tourism aspect by functioning as a place for trying the local culinary menu. In Hulu Sungai Selatan, it is important for the restaurant owner and local government to promote local cuisines. The restaurant owner, local government, and related group in the culinary industry together should be able to promote and make up an authentic traditional menu, in which the tourism get the chance to experience the local food. In such a case, the active involvement of community was essential [11].

Health facility was provided to support community needs to meet basic health standard and diseases problems. It includes city hospitality, public health service in each district (Puskesmas, Puskemas Pembantu, Polindes), and drug store. However, the facility can also be used to support amenity for tourism development by improving standard services in some aspects.

Freshwater is the basic resources for live and important to support many aspect of life, including tourism. As far, the supply of water was adequate to support tourism development. Freshwater extruded from spring, river and well. In some place, freshwater was supported by Regional water company (PDAM) while electricity was supported by National Electricity Company (PLN).

\section{The Development of Tourism}

The development of tourism in Hulu Sungai Selatan should be able to bring all resources into systematic planning with the sustainable tourism vision. Recently, the issues of sustainable tourism increase as a response to mass and unplanned tourism activity that contribute to the numerous degradations in social and environmental aspects [12]. Uncontrolled tourism development and its impact have been reported widely, and it is become an important point for Hulu Sungai Selatan to consider the sustainable development practices in tourism sectors.

Ecotourism seems to be potentials to develop. It is especially important to support local economic growth in the framework of sustainable environmental and biodiversity conservation [13]. It is especially important because South Kalimantan is the home of numerous tropical biodiversity in the globe. The tropical forest has been identified important in global warming issues, and therefore involving tropical forest management in the tourism sector is important.

The development of eco-lodge is through the empowerment of local settlement as communitybased tourism accommodation. Besides contributing to the effort in increasing local economic earning, the eco-lodge significantly contributes to the global warming mitigation [14]. The design of eco-lodge principally should be able to involve local people participation and adopt the local culture and tradition. It is especially important to promote local genuine of local community [15].

\section{CONCLUSION}

Hulu Sungai Selatan Regency has numerous potential tourism objects, ranging from manmade to natural attractions. On the future development, special interest tourism such as nature-based tourism, ecotourism, culinary tourism, religious tourism, history and cultural tourism are potentials to be developed. The tourism potentiality recorded in this study has similarities with other reports from tourism and natural resources study, in which formulating sustainable uses of natural resources through ecotourism implementation is important.

\section{REFERENCES}

[1] Rahajoe, J. S., and T. Kohyama. 2003. Effects of forest fire on leaf litter decomposition of two dominant species (Tristaniopsis obovata and Calophyllum pulcherrimum) in a 
heath forest of South Kalimantan. Tropics 12(4), 277-286.

[2] MacKinnon, K. 1996. The ecology of Kalimantan. Oxford University Press. Oxford.

[3] Jannah, A. R. 2007. Pengelolaan Taman Wisata Alam Pulau Kembang, Banjarmasin, Kalimantan Selatan. Thesis. Faculty of Fisheries and Marine Sciences. Bogor Agricultural University. Bogor.

[4] McKercher, B., H. D. Cros, and R. B. McKercher. 2002. Cultural tourism: the partnership between tourism and cultural heritage management. Haworth Hospitality Press. New York.

[5] Epler, B. 2007. Tourism, the economy, population growth, and conservation in Galapagos. Charles Darwin Foundation. Ecuador.

[6] Hakim, L. 2004. Dasar-dasar ekowisata. Bayumedia. Malang.

[7] Regional Development and Planning Agency of Hulu Sungai Selatan. Map of Hulu Sungai Selatan Regency. Hulu Sungai Selatan Regency.

[8] Hulu Sungai Selatan Regency. 2011. Statistics Hulu Sungai Selatan Regency. Available at: http://hulusungaiselatankab. bps.go.id.

[9] MacDonald, R. and L. Jolliffe. 2003. Cultural rural tourism: evidence from Canada. Annuals of Tourism Research 30(2), 307322.

[10] Le, W., K. Zhang, C. Liu, Q. Xue. 2006. Tourism's impacts on natural resources: a positive case from China. Environmental Management 38, 572-579.

[11] Tosun, C. 2000. Limits to community participation in the tourism development process in developing countries. Tourism Management 21(6), 613-633.

[12] Liu, Z. 2003. Sustainable tourism development: a critique. Journal of Sustainable Tourism 11(6), 459-475.

[13] Aronsson, L. 2000. The Development of Sustainable Tourism. Continuum. London.

[14] Hakim, L., and N. Nakagoshi. 2014. Ecotourism and climates changes: the ecolodge contribution in global warming mitigation. Journal of Tropical Life Science 4(1), 26-32.

[15] Levy, S. E. and D. E. Hawkins. 2010. Peace through tourism: commerce based principles and practices. Journal of Business Ethics 89, 569-585. 